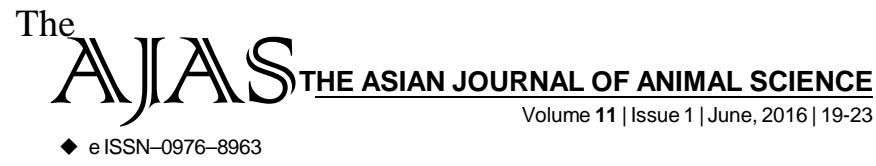

DOI : 10.15740/HAS/TAJAS/11.1/19-23
Visit us | www.researchjournal.co.in

RESEARCH ARTICLE.

\title{
Efficacy of biofermenter on shrimp head waste using Lactobacillus brevis (MTCC 1750)
}

TANUSHRI GHORAI, K.C. DORA, SREEKANTA SARKAR, S. CHOWDHURY AND R. BORDOLOI

ABSTRACT...... The shellfish processing industry in India generates about 8.5 million tonnes of waste per year which is rich in protein $(40.37 \pm 0.74)$ with excellent amount of amino acid and can effectively be substituted in fish meal for feed preparation. The utilization of available protein in shrimp head meal by fishes is limited due to the presence of crude fibre (chitin). Fermentation can reduce this crude fibre by the breakdown of glycosidic bond between protein and chitin converting the product easily digestible. Fermentation of shrimp head

Author for Corresponding -

\section{K.C. DORA}

Department of Fish Processing Technology, Faculty of Fishery Sciences, West Bengal University of Animal and Fishery Sciences, KOLKATA (W.B.) INDIA

Email: kc_dora@yahoo.co.in

See end of the article for

Coopted authors' waste in biofermenter reduces the fermentation time substantially as compared to conventional method.

KEY WORDS...... Shrimp head waste, Proximate composition, Lactobacillus brevis, Fermentation, Biofermenter

HOW TO CITE THIS ARTICLE - Ghorai, Tanushri, Dora, K.C., Sarkar, Sreekanta, Chowdhury, S. and Bordoloi, R. (2016). Efficacy of biofermenter on shrimp head waste using Lactobacillus brevis (MTCC 1750). Asian J. Animal Sci., 11(1): 19-23 (DOI : 10.15740/HAS/TAJAS/11.1/19-23).

ARTICLE CHRONICLE - Received : 28.12.2015; Revised : 20.04.2016; Accepted : 12.05.2016

\section{INTRODUCTION}

Shrimp processing is one of the major food industries in India which are normally marketed as headless and often with exoskeleton removed. Only 40 per cent of the shrimp is edible and remaining 60 per cent considered as processing discards (Sindhu and Sherief, 2011). The solid waste generated in Indian shrimp processing industry was to the tune of 125,000 to 150,000 tonne per annum (Ramyadevi et al., 2012). These discards find very little practical application at present and are categorized as a major environmental contaminant. Effective utilization of this waste can resolve many of the environmental concerns facing the shellfish processors (Shahidi et al., 1992).

Continued production of the shrimp head waste without corresponding development of technology utilizing the waste has resulted in waste collection, disposal and pollution problems. The unused shell of shrimps is a good source of protein with excellent amino acid profile, fat and minerals and can offer a potential source for exploitation as fish feed (Nargis et al., 2006).

This abundant waste may pose a disposal problem and contributes to the overall cost of production. To solve this problem, it is important to transform waste into either silage or mill and use this material in the formulation of fish feed (Meyers, 1986). However, the use of shrimp head meal in the formulation of fish feed is not recommended due to its high fibre and ash contents, which results in the formation of weak pellets with poor stability in water. According to Fagbenro et al. (1997), 